\title{
Microbiological quality of lettuce (Lactuca sativa) irrigated with wastewater in Addis Ababa, Ethiopia and effect of green salads washing methods
}

\author{
Desta Woldetsadik ${ }^{1 *}$, Pay Drechsel ${ }^{2}$, Bernard Keraita ${ }^{3}$, Fisseha Itanna ${ }^{4}$, Berhanu Erko ${ }^{5}$ and Heluf Gebrekidan ${ }^{1}$
}

\begin{abstract}
Background: In Addis Ababa, where irrigation water for vegetable production is commonly derived from the highly polluted Akaki river, information on microbial contamination of water and irrigated vegetable is scanty. An assessment was done to determine the microbiological quality of irrigation water and lettuce harvested from 10 urban farming sites of Addis Ababa. The efficacy of 5 lettuce washing methods were also assessed. A total of 210 lettuce and 90 irrigation water samples were analyzed for faecal coliform and helminth eggs population levels.

Results: The mean faecal coliform levels of irrigation water ranged from 4.29-5.61 $\log _{10}$ MPN $100 \mathrm{ml}^{-1}$, while on lettuce, the concentrations ranged from 3.46-5.03 $\log _{10}$ MPN $100 \mathrm{~g}^{-1}$. Helminth eggs and larvae were detected in $80 \%$ of irrigation water and $61 \%$ of lettuce samples. Numbers ranged from 0.9-3.1 eggs $1000 \mathrm{ml}^{-1}$ and 0.8-3.7 eggs $100 \mathrm{~g}^{-1}$ wet weight for irrigation water and lettuce, respectively. The helminth eggs identified included those of Ascaris lumbricoides, Hookworm, Enterobius vermicularis, Trichuris trichiura, Taenia and Strongloyides larvae. Ascaris lumbricoides and Hookworm were most prevalent in both irrigation water and lettuce samples. Compared with the WHO recommendations and international standards, the faecal coliform and helminth eggs levels in irrigation water and lettuce samples exceeded the recommended levels. Irrespective of the tested washing methods, faecal coliform and helminth eggs levels were somehow reduced. Among the washing methods, potable tap water washing - rinsing (2 min) followed by dipping in 15000 ppm vinegar solution for a minute supported the highest faecal coliorm reduction of $1.7 \log _{10}$ units, whereas lowest reduction of $0.8 \log _{10}$ units was achieved for the same procedure without vinegar.

Conclusion: Compared with international standards, both faecal coliform and helminth eggs levels exceeded recommended thresholds in water and lettuce, but still in a potential risk range which can be easily mitigated if farmers and households are aware of the potential risk. Aside preventing occupational exposure, potential risk reduction programs should target households which have so far no guidance on how best to wash vegetables. The result of the present study suggest that the vinegar based washing methods are able to reduce faecal coliform towards low level while the physical washing with running water may help to substantially decrease potential risk of helminth parasitic infections.
\end{abstract}

Keywords: Faecal coliform, Helminth eggs, Wastewater, Lettuce, Potential risk, Washing, Mitigation, WHO, Addis Ababa

\footnotetext{
* Correspondence: destowol@yahoo.com

'School of Natural Resources Management and Environmental Sciences,

Haramaya University, 138 Dire Dawa, Ethiopia

Full list of author information is available at the end of the article
} 


\section{Background}

In most urban and peri-urban cities of developing countries, the use of untreated, partially treated or diluted wastewater for agriculture is a common practice (Scott et al. 2004; Raja et al. 2015). Market proximity, high opportunities for income generation, reliable and free irrigation water supply, and minimum artificial fertilizer requirement are the often cited benefits of irrigation within cities (Drechsel et al. 2006; Raschid-Sally and Jayakody 2008; Qadir et al. 2010; Lyu et al. 2016). However, the same studies also report high levels of pathogen indicator organisms or also heavy metals in vegetables grown with polluted urban water sources.

The increase of 'wastewater irrigation' is however in most cases not farmers' choice (Raschid-Sally and Jayakody 2008). In Africa, the number of people without access to adequate water and sanitation facilities has risen swiftly in recent decades as the continent's rapid urbanization outpaced its capacity to provide the essential water and sanitation services. In Addis Ababa, large volumes of untreated wastewater are released to water bodies which farmers use for irrigation (Weldesilassie et al. 2011a, b). According to Nuttal (2011), not only liquid waste provides a challenge, but also solid waste dumped along Addis Ababa main river, near bridges and shores of small tributaries where it is washed into the river. Despite all potential risks, irrigated farming of high value crops is livelihood to many urban residents since it provides employment and income (Weldesilassie et al. 2009). About, 60\% of the city's vegetable consumption, particularly lettuce, Swiss chard and Ethiopian Kale, is supplied by urban farmers who irrigate their crops using polluted river water or diluted wastewater (Nuttal 2011). Hence, vegetables produced under such poor sanitation are vulnerable for contamination (Heaton and Jones 2008; Qadir et al. 2010; Blaak et al. 2015). Notably, lettuce which is the main raw vegetable grown in contaminated water irrigated farms need to get special consideration since potential pathogenic microorganisms that get in contact may survive for quite some time and could pose potential health concerns for consumers (Beuchat et al. 2001; Aruscavage et al. 2006; Qadir et al. 2010).

Information on the bacteriological and parasitological aspects of wastewater cropping system and potential health risks associated with the practice is scanty (Guchi and Ashenafi 2010; Habtu 2011). Aside excreta borne pathogens, also heavy metals can be a potential risk factor where industrial effluent enters the common water sources as discussed by Itanna (1998, 2002), Fitamo et al. (2007) and Weldegebriel et al. (2012). The data verify concentrations of selected metals above irrigation water thresholds but limited plant uptake due to high soil $\mathrm{pH}$, cation exchange capacity and clay content (Weldegebriel et al. 2012).

To assess potential pathogenic risk level, our study tried to determine actual evidence of faecal coliform and helminth eggs contamination of irrigation water and lettuce produced on a representative range of Addis Ababa's urban farming sites. To protect produce consumers, WHO (2006) proposes multiple barrier management approaches that encompasses wastewater treatment, crop restrictions (planting non-food and non-raw eaten produce), safer water application methods that reduce produce contamination, improved food hygiene and better cooking of food (Amoah et al. 2007b). In the present study, the efficacy of one of the WHO recommended interventions along the farm to food pathway, which is improving food hygiene through effective washing of contaminated vegetables during food preparation, was also evaluated.

\section{Methods}

\section{Study area}

This study was conducted in Addis Ababa, Ethiopia, where urban farmers have been practicing vegetable production for 55-60 years at various urban farming sites along the Akaki River ('Tinishu' and 'Teleku' Akaki Rivers). The areas covered are ten prominent vegetable farming sites, locally known as Sore Amba, Lekunda, Peacock- Urael, PeacockBole, Kera, Mekanissa, Lafto, Hana-Mariam, Akaki 08, Akaki (Fig. 1) located at five sub-city administrative areas: Kolfe Keraniyo, Chirkos, Bole, Nefas Silk Lafto and Akaki Kaliti, which lies in $038^{\circ} 41^{\prime} \mathrm{E}$ to $038^{\circ} 47^{\prime} \mathrm{E}$ and $08^{\circ} 52^{\prime} \mathrm{N}$ to $9^{\circ} 02^{\prime} \mathrm{N}$. Currently, more than 800 ha of land are irrigated for vegetable production using water from the Akaki River (Weldesilassie and Nigussie 2011).

With the exception of Akaki 08 and Akaki farming sites, at all other sites the manual construction of traditional weirs using sand bags and coarse stones is the most common method to block the water flow till it can enter a system of irrigation channels which follow gravity to support farms further downstream. In these farming sites, vegetable crops, mainly leafy vegetable such as lettuce, Ethiopian Kale and Swiss chard, are grown using furrow irrigation method, by manually opening and closing furrows constructed within the farms. In addition to furrow irrigation technique, flood irrigation, by which fields are flooded in a controlled manner by manually opening and closing of a bund, is also used at Sore Amba, Lekunda, Peacock- Urael, and Peacock-Bole farming sites. At Akaki 08 and Akaki farming sites, the vast majorities of farmers use diesel motor pumps to extract water directly from the river and transport to farm using connected plastic pipes. Some farmers at Lafto farming sites also follow similar water extraction methods. Among the farming sites, the use of agricultural inputs such as inorganic fertilizers and manures is very common at Sore Amba and Lekunda farming sites. Lettuce was selected for this study since it is the only raw eaten leafy vegetable produced in the study area, i.e. the one crop with the highest potential risk for consumers. Sampling was done from November 2013 to 


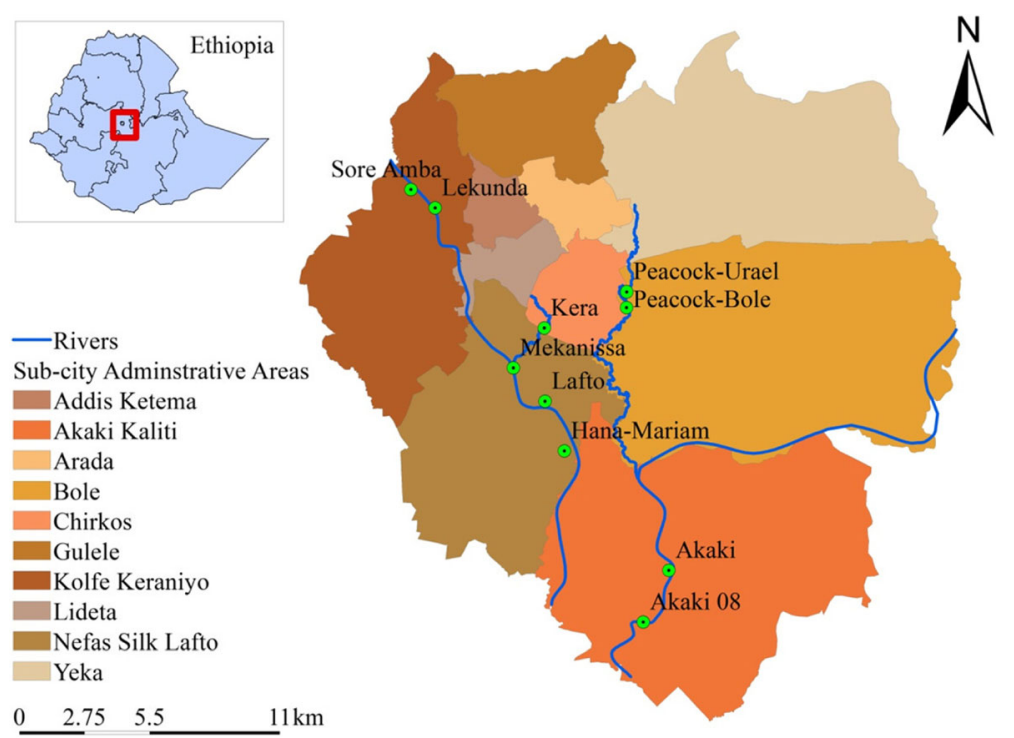

Fig. 1 Map of the sampling sites

March 2014 which was the dry season when irrigation frequency is highest.

\section{Sample collection}

At all farming sites, water was collected at a point where farmers fetch/collect, or where it enters the farm via canals between 8 and 10 o'clock. From each of the farming sites, 9 water samples, triplicate samples from three different fetching points/inlets to farm, were collected in $1 \mathrm{l}$ sterilized glass bottles and transported in an icebox to the laboratory where they were stored at $4{ }^{\circ} \mathrm{C}$ until faecal coliform and helminth eggs analysis.

At each farming site, which is depending on its size operated by $5-25$ farmers, 5 different vegetable farms were selected and 75 lettuce samples ( 5 vegetable farms * 3 plots per farm * 5 lettuce samples from each plot) were harvested in the morning (8 to 10) and made into 15 composite samples. The lettuce samples were packed in sterile polyethylene bags and transported in an icebox to the laboratory where they were stored at $4{ }^{\circ} \mathrm{C}$ until faecal coliform and helminth eggs analysis. Analysis for faecal coliform and helminth eggs started within few hours after collection.

During sample collection period (November 2013 to March 2014), the mean minimum monthly temperature ranged from 4.1 to $8.8^{\circ} \mathrm{C}$. Whereas, the mean maximum monthly temperature ranged from 25.1 to $29.1{ }^{\circ} \mathrm{C}$ (National Meteorological Agency of Ethiopia). Taking into account the time of sample collection, the sampling temperature might be a bit higher than the mean minimum monthly temperature but much lower than the maximum monthly temperature.

\section{Consumer survey on common green salads washing methods}

Based on the analysis and recommendations from Guchi and Ashenafi (2010) to thoroughly wash vegetables eaten raw in Addis Ababa and/or to dip them in food grade antibacterial chemicals for a considerable time, a short survey of 200 households was undertaken to understand how green salads are commonly washed at home. This short survey was carried out in 5 sub-city administrative areas (Kolfe Keraniyo, Chirkos, Bole, Nefas Silk Lafto and Akaki Kaliti). Questionnaire interview were administered to gather information on daily intake pattern of selected leafy vegetables including lettuce and common washing methods used before serving salad. Based on the results, 5 pattern of green salads washing methods emerged although concentration of sanitizers and time used varied considerably among households (Table 1). There was no particular (official) guidance in this matter known, and practices were based on belief or recommendations from peers. Among the 5 green salads washing methods used by survey respondents, four, which reflect common habits, were selected. Conventional laundry detergents are derived from petrochemicals and often contain synthetic fragrances. In general, this type of chemical entities are insoluble in water, easily leaving residue onto the vegetable under washing. Consequently, any residue which may accumulate in human organs cause harmful effect to health overtime (Iovdijova and Bencko 2010). Therefore, the results of laundry detergent washing were not reported in this paper. Although commercial vegetable washing agents, chlorine based agents, have been authorized for use with food in Ethiopia (Codex Alimentarius Commission, 2010), they 
Table 1 Green salads washing methods used in five sub-city administrative areas of Addis Ababa

\begin{tabular}{|c|c|c|c|c|c|c|}
\hline \multirow[t]{2}{*}{ Washing methods } & \multicolumn{6}{|c|}{ Sub-city Administrative Areas/ percentage of respondents } \\
\hline & $\begin{array}{l}\text { Kolfe Keraniyo } \\
(n=39)\end{array}$ & $\begin{array}{l}\text { Chirkos } \\
(n=32)\end{array}$ & $\begin{array}{l}\text { Bole } \\
(n=27)\end{array}$ & $\begin{array}{l}\text { Nefas Silk Lafto } \\
(n=45)\end{array}$ & $\begin{array}{l}\text { Akaki Kaliti } \\
(n=57)\end{array}$ & Total (\%) \\
\hline Potable tap water & 44 & 69 & 26 & 51 & 49 & 47 \\
\hline Salt solution & 18 & 12 & 11 & 9 & 16 & 14 \\
\hline Vinegar solution & 8 & 0 & 19 & 7 & 5 & 6 \\
\hline Detergent solution & 28 & 19 & 37 & 31 & 30 & 31 \\
\hline Commercial vegetable sanitizer & 2 & 0 & 7 & 2 & 0 & 2 \\
\hline
\end{tabular}

are very rarely used for vegetable washing. Hence, they were not included in the washing trial. Accordingly, concentrations of sanitizers and contact time were compared with previous studies in West Africa (Amoah et al. 2007b), the vinegar based washing method was portioned into 2: one with salt $(\mathrm{NaCl})$ and the other without. Overall, 5 washing methods were tested but 4 were presented in this paper, excluding detergent washing. Lettuce samples were collected from two urban farming sites in Addis Ababa. The lettuce samples were pooled, homogenized and transported in an icebox to the laboratory where they were stored at $4{ }^{\circ} \mathrm{C}$ until faecal coliform and helminth eggs analysis. Lettuce leaves weighting $125 \mathrm{~g}$ each were selected for washing trial. Lettuce samples used to determine the initial faecal coliform and helminth eggs levels were also originated from the same pool. Then, $125 \mathrm{~g}$ of each lettuce sample was subjected to the following washing methods in bowls (immersion) and compared with the pre-treatment condition. Analysis for faecal coliform and helminth eggs started within few hours after collection and immediately after washing.

T0: Control (unwashed)

T1: Potable tap water washing and rinsing (2 min)

T2: Potable tap water washing - rinsing (2 min) followed by dipping in 40 ppm salt solution ( $1 \mathrm{~min}$ );

T3: Potable tap water washing - rinsing (2 min) followed by dipping in 15000 ppm vinegar solution (1 min) and

T4: Potable tap water washing - rinsing (2 min) followed by dipping in a combined 40 ppm salt and $15000 \mathrm{ppm}$ vinegar solution (1 min).

The lettuce leaves were cut into pieces using a sterile knife and disposable gloves were used during handling. Following washing, samples were removed with the aid of a sterile stainless steel spatula and dried for 3-5 min. For faecal coliform analysis, $25 \mathrm{~g}$ of each lettuce sample were washed by shaking thoroughly with $225 \mathrm{ml}$ of $0.1 \%$ sterile peptone water. For helminth eggs analysis, a portion of lettuce sample was weighted $(100 \mathrm{~g})$ and washed with $0.1 \%$ Tween 80 solution and the washing water was left overnight for sedimentation to take place. The control samples were simultaneously analyzed with the treated samples. Investigation of faecal coliform and helminth eggs reductions on lettuce using the various washing methods were performed in 10 batches at three days interval. The lettuce samples were taken for analysis at day 1 , day 4 , day 7 , day 10 , day 13 , day 16 , day 19 , day 22, day 25 and day 28. Briefly, the first batch of lettuce samples were collected at day 1 and the last batch at day 28. Overall, each washing method was tested (replicated) ten times.

\section{Bacteriological and parasitological analysis}

The most probable number (MPN) method was used to determine faecal colifrom concentrations of irrigation water and lettuce samples. Seven fold serial dilutions were made. Presumptive and confirmatory tests were performed using 5 tubes per dilution. In the presumptive test, a set of 5 tubes of Lauryl Sulfate Tryptose broth (LST) was inoculated with samples from each dilution and incubated in at $35{ }^{\circ} \mathrm{C}$ for $48 \mathrm{~h}$ in a thermo-regulated water bath. Briefly, $1 \mathrm{ml}$ of serial dilutions in $9 \mathrm{ml}$ of $0.1 \%$ sterile peptone water of the homogenate was inoculated in tubes containing LST and durham tube. After incubation at $35^{\circ}$ $\mathrm{C}$ for $48 \mathrm{~h}$, a loopful of suspension $(1 \mathrm{ml})$ from positive tubes of LST broth was transferred to Escherichia coli broth (EC) tubes and incubated at $45{ }^{\circ} \mathrm{C}$ for $24-48 \mathrm{~h}$ in a thermo-regulated water bath. Tubes exhibiting acid or gas production were considered positive. The number and distribution of positive tubes were used to obtain the population of faecal coliform in water and lettuce samples from MPN table.

A modification of Bailenger method (Ayres and Mara 1996) was used for enumeration of helminth eggs. Briefly, each lettuce sample $(100 \mathrm{~g})$ was washed with $0.1 \%$ Tween 80 solution. The washing water was left overnight for sedimentation to take place and $90 \%$ of the supernatant was discarded and the remaining washing water and sediment were centrifuged at $1500 \mathrm{~g}$ for $5 \mathrm{~min}$. The supernatant was discarded, the sediment was suspended in equal volume of acetoacetic buffer, followed by the addition of two volumes of ether, thoroughly mixed using vortex mixer and centrifuged at $1000 \mathrm{~g}$ for $15 \mathrm{~min}$. The volume of the 
pellet containing the eggs was recorded and the rest of the supernatant was discarded in one smooth action. The pellet was resuspended in five volume of $\mathrm{ZnSO}_{4}$ solution, thoroughly mixed using vortex mixer and exhaustively examined under light microscope. The same method was used to quantify helminth eggs in irrigation water samples. The bench-aid for the diagnosis of intestinal parasites (WHO 1994) was used for identification purpose.

\section{Statistical analysis}

Faecal coliform concentrations were normalized by $\log$ transformation before analysis of variance. One-way analysis of variance and Duncan's multiple range tests were employed to compare mean of log transformed faecal coliform levels and helminth eggs concentrations found from lettuce and irrigation water by farming sites. For lettuce washing methods, Kruskal-Wallis $\mathrm{H}$ test was applied and, when necessary, a nonparametric multiple comparison test using SPSS package since the statistical assumptions of normality were not met. A statistically significant difference was assumed at the $5 \%$ level.

\section{Results}

\section{Green salads washing methods used by respondents}

Based on the results, 5 pattern of green salads washing methods emerged although concentration of sanitizers and washing time used varied considerably among households (Table 1). Forty- seven percent of the respondents responded that they only use potable tap water to wash salads and more than $30 \%$ indicated that they prepare detergent solution for washing purpose. Various types of detergents/soaps were indicated by this group of household. Fourteen percent of respondents reported that they wash green salads using salt solution, yet $6 \%$ use vinegar solution. However, only $2 \%$ use commercial vegetable sanitizer. Further sanitization of green salads is likely as vinegar/vegetable oil or salt/vegetable oil or salt/lemon/vegetable oil are commonly used for dressing purpose.

Faecal coliform concentrations in irrigation water and lettuce The irrigation water from the 10 farming sites had mean faecal coliform concentrations ranging from 4.29-5.61 $\log _{10} \mathrm{MPN} 100 \mathrm{ml}^{-1}$ (Table 2). Analysis of variance revealed that irrigation water collected from Lekunda farming site had significantly higher mean faecal coliform level (5.61 $\log _{10} \mathrm{MPN} 100 \mathrm{ml}^{-1}$ ) than in irrigation water from other farming sites (Peacock-Bole, Mekanissa, Lafto, Hana-Mariam and Akaki 08) while in irrigation water from Hana-Mariam, the mean faecal coliform counts were the lowest. No significant differences $(P>0.05)$ were observed in mean faecal coliform concentrations of irrigation water from the five farming sites (Sore Amba, Lekunda, Peacock-Urael, Kera and Akaki). Irrespective of the farming sites, the values did not meet the WHO (1989) guide line value of $\leq 10^{3} / 100 \mathrm{ml}$ in case of unrestricted irrigation for crops that are likely to be eaten raw.

The mean faecal coliform concentrations in lettuce ranged from 3.46-5.03 $\log _{10}$ MPN $100 \mathrm{~g}^{-1}$ (Table 2). The highest mean faecal coliform was recorded in lettuce from Lafto farming site, while the lowest level was found from Peacock-Bole. With the exception of the two farming sites, lettuce collected from all other farming sites were similarly contaminated with faecal coliform. All mean faecal coliform values recorded on lettuce exceeded recommended threshold of less than $10^{3} / 100 \mathrm{~g}$ fresh weight.

\section{Helminth eggs levels in irrigation water and lettuce}

The mean helminth eggs and larvae detected in irrigation water ranged from 0.9 to 3.1 eggs $1000 \mathrm{ml}^{-1}$ (Table 3). Eighty percent of the irrigation water samples were found to be contaminated with one or more helminth eggs. Analysis of variance revealed that the mean helminth eggs concentration (3.1 eggs $1000 \mathrm{ml}^{-1}$ ) found in irrigation water of Lekunda farming site was significantly higher than that of

Table 2 Mean faecal coliform contamination levels of irrigation water and irrigated lettuce from ten farming sites in Addis Ababa

\begin{tabular}{|c|c|c|c|c|c|c|c|c|c|c|}
\hline \multirow[t]{2}{*}{ Sample type } & \multicolumn{10}{|l|}{ Farming sites } \\
\hline & Sore Amba & Lekunda & Peacock-Urael & Peacock-Bole & Kera & Mekanissa & Lafto & Hana-Mariam & Akaki 08 & Akaki \\
\hline \multicolumn{11}{|c|}{ Irrigation Water ( $N=9$ for each farming site) } \\
\hline Range & $3.23-6.73$ & $4.51-6.96$ & $3.65-5.54$ & $2.83-6.23$ & $3.04-6.73$ & $3.59-5.67$ & $3.51-7.20$ & $2.96-5.64$ & $3.58-5.41$ & $3.51-6.15$ \\
\hline $\begin{array}{l}\text { Mean } \\
\left(\log _{10} \text { MPN }\right. \\
\left.100 \mathrm{ml}^{-1}\right)\end{array}$ & $5.06(1.01)^{\mathrm{abc}}$ & $5.61(0.70)^{a}$ & $5.02(0.64)^{a b c}$ & $4.67(1.04)^{b c}$ & $4.82(1.02)^{\mathrm{abc}}$ & $4.57(0.54)^{b c}$ & $4.52(1.18)^{b c}$ & $4.29(0.70)^{c}$ & $4.58(0.66)^{b c}$ & $5.24(0.75)^{a b}$ \\
\hline \multicolumn{11}{|c|}{ Lettuce ( $N=15$ for each farming site) } \\
\hline Range & $2-81-4.72$ & $2.66-5.18$ & $3.04-6.96$ & $2.83-4.30$ & $3.04-5.67$ & $2.96-5.32$ & $3.23-6.96$ & 2.83-5.15 & $2.65-4.64$ & $3.15-7.20$ \\
\hline $\begin{array}{l}\text { Mean } \\
\left(\log _{10} \text { MPN }\right. \\
\left.100 \mathrm{~g}^{-1}\right)\end{array}$ & $3.91(0.73)^{b c}$ & $4.18(0.74)^{\mathrm{bc}}$ & $4.10(1.00)^{\mathrm{bc}}$ & $3.46(0.44)^{c}$ & $4.05(0.80)^{b c}$ & $3.93(0.84)^{b c}$ & $5.03(1.38)^{a}$ & $3.69(0.58)^{\mathrm{bc}}$ & $3.50(0.59)^{c}$ & $4.19(1.01)^{b c}$ \\
\hline
\end{tabular}

Figures in parentheses represent standard deviation

Values in the same row with different letters differ significantly $(p<0.05)$ 
Table 3 Mean helminth eggs contamination levels of irrigation water and irrigated lettuce from ten farming sites in Addis Ababa

\begin{tabular}{|c|c|c|c|c|c|c|c|c|c|c|}
\hline \multirow[t]{2}{*}{ Sample Type } & \multicolumn{10}{|c|}{ Farming Sites } \\
\hline & Sore Amba & Lekunda & Peacock-Urael & Peacock-Bole & Kera & Mekanissa & Lafto & Hana-Mariam & Akaki 08 & Akaki \\
\hline \multicolumn{11}{|c|}{ Irrigation Water ( $N=9$ for each farming site) } \\
\hline Ascaris lumbricoides & 14 & 21 & 19 & 16 & 20 & 7 & 17 & 12 & 18 & 16 \\
\hline Hookworm & 3 & 3 & 2 & 1 & 3 & 1 & 1 & 2 & 2 & 3 \\
\hline Enterobius vermicularis & 0 & 1 & 2 & 1 & 0 & 0 & 0 & 1 & 1 & 0 \\
\hline Trichuris trichiura & 1 & 1 & 1 & 0 & 1 & 0 & 0 & 1 & 0 & 0 \\
\hline Taenia & 0 & 0 & 0 & 0 & 2 & 0 & 1 & 0 & 0 & 0 \\
\hline Heymenolepis nana & 1 & 1 & 2 & 0 & 0 & 0 & 0 & 0 & 0 & 0 \\
\hline Strongloyides & 0 & 1 & 0 & 0 & 0 & 0 & 1 & 0 & 0 & 1 \\
\hline Total & 19 & 28 & 26 & 18 & 26 & 8 & 20 & 16 & 22 & 20 \\
\hline Mean ${ }^{x}$ & $2.1(1.2)^{\mathrm{ab}}$ & $3.1(2.1)^{\mathrm{a}}$ & $2.9(1.8)^{\mathrm{a}}$ & $2.0(1.7)^{\mathrm{ab}}$ & $2.9(1.9)^{\mathrm{a}}$ & $0.9(0.8)^{b}$ & $2.2(1.6)^{\mathrm{ab}}$ & $1.8(1.6)^{\mathrm{ab}}$ & $2.4(2.2)^{\mathrm{ab}}$ & $2.2(1.7)^{\mathrm{ab}}$ \\
\hline \multicolumn{11}{|c|}{ Lettuce ( $N=15$ for each farming site) } \\
\hline Ascaris lumbricoides & 20 & 28 & 25 & 17 & 20 & 16 & 42 & 25 & 10 & 31 \\
\hline Hookworm & 1 & 2 & 2 & 3 & 4 & 2 & 5 & 4 & 2 & 3 \\
\hline Enterobius vermicularis & 0 & 1 & 1 & 1 & 0 & 0 & 3 & 0 & 0 & 2 \\
\hline Trichuris trichiura & 0 & 1 & 0 & 0 & 1 & 1 & 3 & 2 & 0 & 1 \\
\hline Taenia & 0 & 0 & 0 & 0 & 1 & 0 & 2 & 0 & 0 & 0 \\
\hline Strongloyides & 0 & 0 & 1 & 0 & 0 & 0 & 1 & 0 & 0 & 0 \\
\hline Total & 21 & 32 & 29 & 21 & 26 & 19 & 56 & 31 & 12 & 37 \\
\hline Mean ${ }^{y}$ & $1.4(1.4)^{b c}$ & $2.1(2.3)^{b}$ & $1.9(1.5)^{b c}$ & $1.4(0.9)^{b c}$ & $1.7(1.7)^{\mathrm{bc}}$ & $1.3(1.3)^{b c}$ & $3.7(2.2)^{a}$ & $2.1(1.8)^{b c}$ & $0.8(1.0)^{c}$ & $2.5(2.2)^{b}$ \\
\hline
\end{tabular}

${ }^{x}$ Mean concentrations of helminth eggs and larvae $1000 \mathrm{ml}^{-1}$

${ }^{y}$ Mean concentrations of helminth eggs and larvae $100 \mathrm{~g}^{-1}$

Figures in parentheses represent standard deviation

Values in the same row with different letters differ significantly $(p<0.05)$

Mekanissa but statistically similar $(P>0.05)$ with the mean values of the other farming sites. The identified helminth eggs and larvae consisted of Ascaris lumbricoides, Hookworm, Enterobius vermicularis, Trichuris trichiura, Taenia, Heymenolepis nana and Strongloyides. A. lumbricoides was the predominant helminth egg. The mean helminth eggs concentration of irrigation water from all farming sites exceeded the WHO (1989) guide value of < 1 egg $1000 \mathrm{ml}$ ${ }^{-1}$ for unrestricted irrigation except Mekanissa.

In lettuce, $61 \%$ of the total samples were positive for one or more helminth eggs. Site wise, the highest mean helminth eggs concentration (3.7 helminth eggs $100 \mathrm{~g}^{-1}$ ) was detected from Lafto farming site, while the lowest (0.8 helminth eggs $100 \mathrm{~g}^{-1}$ ) was from Akaki 08 farming site. Ascaris lumbricoides, Hookworm, Enterobius vermicularis, Trichuris trichiura, Taenia and Strongloyides were detected in lettuce samples. A. lumbricoides was most prevalent followed by Hookworm.

\section{Effects of washing methods}

Irrespective of washing methods, faecal coliform levels of lettuce were reduced by 0.8 to $1.7 \log _{10}$ units (Table 4). As compared to the control, all washing methods were able to support significant reduction of faecal coliform.
The vinegar based washing methods induced significant faecal coliform reduction compared with potable tap water washing methods (with or without salt). Similarly, the washing methods induced helminth eggs reduction by $1-2$ eggs (Table 4 ).

\section{Discussion}

This study shows that irrespective of the farming sites, almost all irrigation water samples had a poor microbiological quality. In the studied sites, there are a number of factors that might potentially cause contamination of irrigation water with relatively high levels of faecal coliform, in particular the inflow from untreated wastewater into the Akaki river (Weldesilassie et al. 2011b). The highest faecal coliform concentration was exhibited in irrigation water from Lekunda farming site. At Lekunda, the proximity of farm lands to resident and cattle houses coupled with almost null proper sanitation service potentially impose an effect on faecal coliform levels in the irrigation water. Thus, grey and black waters originated from households appear to be the key source of faecal contamination. This is consistent with the studies by Fischer et al. (Fisher et al. 2000), Monaghan et al. (2009), Wittman et al. (2013) and Schreiber et al. (2015) who 
Table 4 Effect of washing methods on the reduction of faecal coliform and helminth eggs levels of lettuce irrigated with polluted water ( $n=10$ for each method)

\begin{tabular}{llllll}
\hline Indicator organisms & Washing methods & & & \\
\cline { 2 - 6 } & T0 & T1 & T2 & T3 & T4 \\
\hline Faecal coliform ( $\left.\log _{10} \mathrm{MPN} 100 \mathrm{~g} \mathrm{~g}^{-1}\right)$ & $4.23^{\mathrm{x}}(0.71)^{\mathrm{a}}$ & $3.43(0.77)^{\mathrm{b}}$ & $3.35(0.61)^{\mathrm{b}}$ & $2.54(0.51)^{\mathrm{c}}$ & $2.58(0.43)^{\mathrm{c}}$ \\
Helminth eggs (eggs $\left.100 \mathrm{~g}^{-1}\right)$ & $2.2^{\mathrm{y}}(1.93)$ & $0.8(1.14)$ & $0.6(0.70)$ & $1.0(1.33)$ & $0.6(0.97)$ \\
Actual egg count (range) & $0-6$ & $0-3$ & $0-2$ & $0-4$ & $0-3$
\end{tabular}

(T0): Control (unwashed) (T1) Potable tap water washing and rinsing ( 2 min); (T2): Potable tap water washing - rinsing ( 2 min) followed by dipping in 40 ppm salt solution (1 min); (T3): Potable tap water washing - rinsing ( $2 \mathrm{~min}$ ) followed by dipping in 15000 ppm vinegar solution (1 min); and (T4): Potable tap water washing - rinsing (2 min) followed by dipping in a combined $40 \mathrm{ppm}$ salt and $15000 \mathrm{ppm}$ vinegar solution (1 $\mathrm{min}$ )

${ }^{x}$ Actual mean faecal coliform level

${ }^{y}$ Actual mean egg count

Figures in parenthesis represent standard deviation

Values in the same row with different letters differ significantly $(P<0.05)$; range of detected helminth eggs too narrow for normal distribution, homogeneity, and statistically significant differences

demonstrated the considerable impact of anthropogenic inputs on microbial quality of river water.

As reflected by water quality, also the lettuce samples from all farming sites had high faecal coliform levels exceeding recommended thresholds, similar to the findings in other sub-Saharan cities (Keraita et al. 2002; Srikanth and Naik 2004; Amoah et al. 2005, 2007a). Compared with studies in Ghana (Amoah et al. 2005, 2007a), the faecal coliform levels are lower in the case of Addis Ababa. The reason can be several: a) the Akaki river offers more dilution than the smaller streams e.g. in Kumasi, b) furrow and flood irrigation reduce leaf contact (Ghana: overhead irrigation with watering cans), and c) irrigation frequency in Addis (1-2 times per week) is much lower than in hot Ghana where lettuce is irrigated twice a day which also allows more natural die-off (Keraita et al. 2002; Amoah et al. 2011). Unfortunately, on some farming sites vegetables including lettuce are washed by farmers and traders with the water used for irrigation to remove soil residues and keep it fresh until selling. As lettuce is not undergoing heat treatment in kitchens salad eating consumers will be potentially at risk. A similar practice was also reported from Ghana (Amoah et al. 2011) and has to be controlled as part of other potential post-harvest contamination risks.

The helminth eggs and larvae detected in irrigation water and lettuce comprised of Ascaris lumbricoides, Hookworm, Enterobius vermicularis, Trichuris trichiura, Taenia and Strongloyides. This corresponds with similar studies in West Africa (Drechsel and Keraita 2014). A slightly higher helminth eggs percentage prevalence (64\%) in lettuce grown in 4 wastewater irrigated farming sites of Addis Ababa was reported by Habtu (2011). In neighboring Kenya, high prevalence of helminth eggs in vegetable was reported Nyarango et al. (2008). Several factors may contribute to difference in percentage prevalence of helminth eggs in vegetable including the quality of irrigation water used, irrigation methods, post harvest handling and methods of quantification (Kozan et al. 2005; Ezatpour et al. 2013; Gil et al. 2015).
This paper does not address farmer exposure to wastewater for which universal risk mitigation measures are well known (WHO 2006), but focuses on potential microbial risks for consumers and washing methods for bacterial and helminth eggs reductions. Our study revealed that all the tested washing methods reported here could somehow significantly reduce faecal coliform levels but only the vinegar based washing support 1.6 to $1.7 \log _{10}$ units reduction. This is less still than the 2-3 $\log _{10}$ units reduction (Amoah et al. 2007b) which are possible by further optimizing the concentration and exposure time. In this study, there were two vinegar based washing methods (one with little salt and the other without) and no significant faecal coliform reduction effect was detected between them. There appears to be no benefit from the practice of using little salt which will be an important message to households.

According to Amoah et al. (2007b), longer contact time and high concentration of sanitizers did promote significant reduction of faecal coliform population. However, they questioned the practicality of increasing contact time and concentrations beyond some levels in light of extra processing time, cost and quality (in terms of appearance and texture) of ready to eat lettuce. Yet, boosting the concentration of salt used in our study to reasonable level may not seem to affect cost and quality. Alternatively, chlorine based commercial vegetable and fruit sanitizers, are considered to be very effective to reduce/kill microbial pathogens. Where these are not easily available, often imported and expensive, also household bleach (sodium hypochlorite) can be effective in sanitizing food, as it is very common in Francophone Africa (Amoah et al. 2007b). In Ethiopia, common bleach is however sold without supplier recommendations for use in food, which increases the risk of misuse. Locally produced vegetable sanitizer (for example, 'G.Melaten') which is based on bleach should therefore get broader promotion to raise potential risk awareness while 
offering an option for potential risk mitigation. A comparative cost analysis showed that with one $1000 \mathrm{ml}$ bottle of 'G.Melaten' (0.7 USD) a household can wash about 70 to 150 salad dishes depending on the optimization of concentration versus a practically (short) contact time, which is 7 to 40 as much as with other (mostly imported) products on the market (Woldetsadik, unpublished). Other factors (type and physiology of the target organisms and characteristics of produce surfaces) could also influence the efficacy of the method used to reduce microbial population (Materon 2003; Parish et al. 2003; Amoah et al. 2007b). Moreover, type of washing (running versus immersion) influences the level of pathogen indicator organisms on fresh produce and therefore influence the final potential risk values. For instance, rinsing under running tap water is considered more effective than immersion, resulting in up to $2.2 \log _{10}$ coli reductions (Pangloli et al. 2009). In case of helminth eggs, all treatments induced comparable reductions effect, which is mostly based on the physical force of washing and rinsing, not a chemical impact (Amoah et al. 2007b; Fallah et al. 2012).

\section{Conclusion}

This study indicated that faecal contamination level of lettuce irrigated with contaminated irrigation water is above the threshold of safe consumption, but in a range which can be addressed through relatively simple and low-cost mitigation measures. The WHO is promoting a multi-barrier approach and one of these barriers can be washing of green salads at home. Post-harvest treatment is important to address post-harvest contamination which can start already on farm when harvested crops are locally washed. The case of Addis Ababa showed in general lower contamination levels than known from West Africa, because of wastewater dilution, different irrigation water application methods and frequency. Aside preventing occupational exposure, potential risk reduction programs should target households which have so far no guidance on how best to wash vegetables. In fact, majority of the survey participants only use tap water and detergent washing methods in spite of their limited microbiological benefits and potential health concerns associated with chemicals in commercial laundry detergents. The result of the present study suggest that the vinegar based washing treatments are able to reduce faecal coliform towards low level while the physical washing with running water may help to substantially decrease potential risk of helminth parasitic infections. The 15,000 ppm vinegar solution is in simple terms approximately mixing one part vinegar with four parts water. It should be noted however that such a ratio will be expensive over time, while vinegar may change the taste or texture of the lettuce leaves. In conclusion, the 2006 WHO guidelines for safe wastewater irrigation put significant emphasis on mitigation of potential risks along the farm to fork pathway, i.e. beyond strict but unachievable irrigation water quality thresholds which supports very well the needs as well as opportunities as observed in Addis Ababa.

\begin{abstract}
Acknowledgements
This work was supported by the International Water Management Institute (IWMI-CGIAR) under the water, Land and Ecosystems Research Program, and the Ministry of Education of Ethiopia. We are grateful to Philip Amoah and Felix Grau for their valuable comments on the manuscript and the staff of Soil Microbiology Laboratory at National Soil Testing Center, Addis Ababa, Ethiopia for the laboratory assistance. We also wish to acknowledge the field work support of development agents at various sub-city administrative areas of Addis Ababa.
\end{abstract}

\section{Authors' contributions}

DW, PD, BK, FI and BE conceived and designed the study. DW conducted the study. DW, PD, BK, FI and BE contributed to the analysis and interpretation of data. DW drafted the manuscript. DW, PD, BK, FI, BE and $\mathrm{HG}$ revised the draft manuscript. All authors read and approved the final manuscript.

\section{Competing interests}

The authors declare that they have no competing interests.

\section{Author details}

${ }^{1}$ School of Natural Resources Management and Environmental Sciences, Haramaya University, 138 Dire Dawa, Ethiopia. ${ }^{2}$ International Water Management Institute, Colombo, Sri Lanka. ${ }^{3}$ UNICEF, Eastern and Southern Africa Regional Office, Nairobi, Kenya. ${ }^{4}$ Department of Crop Science, University of Namibia, Windhoek, Namibia. ${ }^{5}$ Aklilu Lemma Institute of Pathobiology, Addis Ababa University, Addis Ababa, Ethiopia.

Received: 19 July 2016 Accepted: 12 January 2017

Published online: 18 January 2017

\section{References}

Amoah P, Drechsel P, Abaidoo RC. Irrigated urban vegetable production in Ghana: sources of pathogen contamination and health risk elimination. Irrig Drainage. 2005;54 Suppl 1:49-61.

Amoah P, Drechsel P, Abaidoo RC. Irrigated urban vegetable production in Ghana: microbiological contamination in farms and markets and associated consumer risk groups. J Water Health. 2007a;5(3):455-66.

Amoah P, Drechsel P, Abaidoo RC, Klutse A. Effectiveness of common and improved sanitary washing methods in selected cities of West Africa for the reduction of coliform bacteria and helminth eggs on vegetables. Trop Med Int Health. 2007b;12 Suppl 2:40-50.

Amoah P, Keraita B, Akple M, Drechsel P, Abaidoo RC, Konradsen F. Low cost options for health risk reduction where crops are irrigated with polluted water in West Africa. IWMI Research Report No. 141. Colombo, Sri Lanka: International Water Management Institute; 2011.

Aruscavage D, Lee K, Miller S, LeJeune JT. Interactions affecting the proliferation and control of human pathogens on edible plants. J Food Sci. 2006;71:R89-99.

Ayres RM, Mara DD. Analysis of Wastewater for Use in Agriculture - A Laboratory Manual of Parasitological and Bacteriological Techniques. Geneva, Switzerland: World Health Organization; 1996.

Beuchat LR, Farber JM, Garrett E, Harris L, Parish ME, Suslow TV, Busta FF. Standardization of a method to determine the efficacy of sanitizers in inactivating human pathogenic microorganisms on raw fruits and vegetables. J Food Prot. 2001;64:1079-84.

Blaak H, Lynch G, Italiaander R, Hamidjaja RA, Schets FM, de Roda Husman AM. Multidrug-resistant and extended spectrum beta-lactamase-producing Escherichia coli in Dutch surface water and wastewater. PLOS One. 2015; 10(6):e0127752.

Drechsel P, Keraita B, editors. Irrigated urban vegetable production in Ghana: characteristics, benefits and risk mitigation. 2nd ed. Colombo, Sri Lanka: International Water Management Institute; 2014. 
Drechsel P, Graefe S, Sonou M, Cofie O. Informal irrigation in West Africa: An overview. IWMI Research Report No. 102. Colombo, Sri Lanka: International Water Management Institute; 2006

Ezatpour B, Chegeni AS, Abdollahpour F, Aazami M, Alirezaei M. Prevalence of parasitic contamination of raw vegetables in Khorramabad, Iran. Food Control. 2013;34(1):92-5.

Fallah AA, Pirali-Kheirabadi K, Shirvani F, Saei- Dehkordi SS. Prevalence of parasitic contamination in vegetables used for raw consumption in Shahrekord, Iran: influence of season and washing procedure. Food Control. 2012;25(2):617-20.

Fisher DS, Steiner JL, Endale DM, Stuedemann JA, Schomberg HH, Franzluebbers AJ, Wilkinson SR. The relationship of land use practices to surface water quality in the upper Oconee Watershed of Georgia. Forest Ecol Manag. 2000; 128(1-2):39-48.

Fitamo D, Itanna F, Olsson M. Total contents and sequential extraction of heavy metals in soils irrigated with wastewater, Akaki, Ethiopia. Environ Manage. 2007;39(2):78-93.

Gil Ml, Selma MV, Suslow T, Jacxsens L, Uyttendaele M, Allende A. Pre- and postharvest preventive measures and intervention strategies to control microbial food safety hazards of fresh leafy vegetables. Crit Rev Food Sci Nutri. 2015;21:453-68.

Guchi B, Ashenafi M. Microbial Load, Prevalence and Antibiograms of Salmonella and Shigella in Lettuce and Green Peppers. Ethiop J Health Sci. 2010;20(1):41-8.

Habtu M. Intestinal parasite contamination of raw vegetables from selected farms and markets in Addis Ababa, Ethiopia. MSc. Thesis, Addis Ababa University. 2011.

Heaton JC, Jones K. Microbial contamination of fruit and vegetables and the behaviour of enteropathogens in the phyllosphere: a review. J Appl Microbiol. 2008;104:613-26.

lovdijova A, Bencko V. Potential risk of exposure to selected xenobiotic residues and their fate in the food chain. I. Classification of xenobiotics. Ann Agric Environ Med. 2010;17:183-92.

Itanna F. Metal concentration of some vegetables irrigated with industrial liquid waste at Akaki, Ethiopia. Sinet: Ethiopian J Sci. 1998;21(1):133-44.

Itanna F. Metals in leafy vegetables grown in Addis Ababa and toxicologica implications. Ethiopian J Health Develop. 2002;6:295-302.

Keraita B, Drechsel P, Huibers F, Raschid-Sally L. Wastewater use in informal irrigation in urban and peri-urban areas of Kumasi, Ghana. Urban Agric Mag. 2002;8:11-3.

Kozan E, Gonenc B, Sarimehmetoglu O, Aycicek H. Prevalence of helminth eggs on raw vegetables used for salads. Food Control. 2005;16(3):239-42.

Lyu S, Chen W, Zhang W, Fan Y, Jiao W. Wastewater reclamation and reuse in China: opportunities and challenges. J Environ Sci. 2016;39:86-96.

Materon LA. Survival of Escherichia coli 0157:H7 applied to cantaloupes and the effectiveness of chlorinated water and lactic acids as disinfectants. World J Microbiol Biotechnol. 2003;19(8):867-73.

Monaghan RM, Carey PL, Wilcock RJ, Drewry JJ, Houlbrooke DJ, Quinn JM, Thorrold BS. Linkages between land management activities and stream water quality in a border dyke-irrigated pastoral catchment. Agric Ecosyst Environ. 2009;129(1-3):201-11.

Nuttal N. Fast pace of African urbanization affecting water supplies and sanitation. United Nations Environment Program, March 21, 2011. Accessed on October 10, 2015. http://www.unep.org/Documents.Multilingual/Default. Print.asp?Document|D=664\&ArticleID=8666\&l=en

Nyarango RM, Aloo PA, Kabiru EW, Nyanchongi BO. The risk of pathogenic intestinal parasite infections in Kisii Municipality, Kenya. BMC Public Health. 2008;8:237

Pangloli P, Hung YC, Beuchat LR, King CH, Zhao ZH. Reduction of Escherichia coli 0157:H7 on produce by use of electrolyzed water under simulated food service operation conditions. J Food Prot. 2009:72:1854-61.

Parish ME, Beuchat LR, Suslow TV, et al. Methods to reduce/eliminate pathogens from fresh and fresh-cut produce. Compr Rev Food Sci F. 2003;2(Suppl):161-73.

Qadir M, Wichelns D, Raschid-Sally L, McCornick PG, Drechsel P, Bahri A, Minhas PS. The challenges of wastewater irrigation in developing countries. Agr Water Manag. 2010;97(4):561-8.

Raja S, Masooma H, Cheema N, Babar S, Khan AA, Murtaza G, Aslam U. Socioeconomic background of wastewater irrigation and bioaccumulation of heavy metals in crops and vegetables. Agr Water Manag. 2015;158:26-34.

Raschid-Sally L, Jayakody P. Drivers and Characteristics of Wastewater Agricutlure in Developing Countries: Results from a Global Assessment. IWMI Research Report No. 127. Colombo, Sri Lanka: International Water Management Institute; 2008.

Schreiber C, Rechenburg A, Rind E, Kistemann T. The Impact of Land Use on Microbial Surface Water Pollution. Int J Hyg Envir Heal. 2015;218(2):181-7.

Scott CA, Faruqui NI, Raschid-Sally L. Wastewater use in irrigated agriculture: Management challenges in developing countries. In: Scott CA, Faruqui Nl, Raschid-
Sally L, editors. Wastewater Use in Irrigated Agriculture: Confronting the Livelihood and Environmental Realities. Wallingford: CABI Publishing; 2004. p. 1-10.

Srikanth R, Naik D. Prevalence of Giardiasis due to wastewater reuse for agriculture in the suburbs of Asmara City, Eritrea. Int J Environ Heal R. 2004;14(1):43-52.

Weldegebriel Y, Chandravanshi BS, Wondimu T. Concentration levels of metals in vegetables grown in soils irrigated with river water in Addis Abada, Ethiopia. Ecotox Environ Safe. 2012;77:57-63.

Weldesilassie A, Nigussie M. Vegetable Production, Marketing and Quality of Irrigation Water and Vegetable Produced within and around Addis Ababa city, Ethiopia. 2011. Unpublished report; 2011

Weldesilassie A, Frör O, Boelee E, Dabbert S. The economic value of improved wastewater irrigation: a contingent valuation study in Addis Ababa, Ethiopia. J Agric Res Econ. 2009;34(3):428-49.

Weldesilassie A, Amerasinghe P, Danso G. Assessing the Empirical Challenges of Evaluating the Benefits and Risks of Irrigating with Wastewater. Water Int. 2011a;36(4):441-54

Weldesilassie A, Boelee E, Drechsel P, Dabbert S. Wastewater use in crop production in periurban areas of Addis Ababa: impacts on health in farm households. Environ Dev Econ. 2011b;16(1):25-49.

WHO. Health guidelines for the use of wastewater in agriculture and aquaculture. Report World Health Organization of Scientific Group. Technical Report Series No. 778. Geneva, Switzerland: Health Organization; 1989.

WHO. Bench Aids for the Diagnosis of Intestinal Parasites. Geneva, Switzerland: World Health Organization; 1994.

WHO. Guidelines for the Sea Use of Wastewater, Excreta and Grey water: Wastewater Use in Agriculture (Volume 2). Geneva, Switzerland: World Health Organization; 2006

WHO/FAO. Joint FAO/WHO Food Standard Program Codex Alimentarius Commission, $34^{\text {th }}$ Session. Kampala, Uganda: Report of the Forty Second Session of the Codex Committee on Food Hygiene; 2010.

Wittman J, Weckerwerth A, Weiss C, Heyer S, Seibert J, Kuennen B, Ingels C, Seigley L, Larsen K, Enos-Berlage J. Evaluation of land use and water quality in an agricultural watershed in the USA indicates multiple sources of bacterial impariment. Environ Monit Assess. 2013;185:10395-420.

\section{Submit your manuscript to a SpringerOpen ${ }^{\circ}$ journal and benefit from:}

- Convenient online submission

- Rigorous peer review

- Immediate publication on acceptance

- Open access: articles freely available online

- High visibility within the field

- Retaining the copyright to your article

Submit your next manuscript at $>$ springeropen.com 